\title{
Miłość niejedno ma imię
}

\section{Tomislav Bogdan, Ljubavi razlike. Tekstualni subjekt u hrvatskoj ljubavnoj lirici 15. i 16. stoljeća, Disput, Zagreb 2012, 339 s.}

Przedkładana publikacja to kolejna, po wydanej w 2003 roku Lica ljubavi. Status lirskog subjekta u kanconijeru Džore Držića, książka Tomislava Bogdana o chorwackiej liryce miłosnej XV i XVI wieku, ukazująca ją w interesujący, a nade wszystko nietradycyjny sposób. Odwołując się do starszych i najnowszych badań, autor czyni przedmiotem refleksji tradycję petrarkistyczną, jej adaptację, rozwój i sfunkcjonalizowanie w oryginalnych dziełach chorwackich, za każdym razem sytuując $\mathrm{w}$ centrum swoich rozważań podmiot liryczny czy też szerzej - podmiot tekstualny. We wcześniejszej rozprawie analizuje twórczość poetycką Džore Držicia, skupiając się na zróżnicowanych aspektach tożsamości subiektu oraz definiuje rodzimy wariant petrarkizmu, a w tym przypadku ujawnia także rygorystyczne powiązanie analizowanej poezji z wielkim wzorcem Il Canzoniere Francesco Petrarki.

W recenzowanym studium Tomislav Bogdan kompleksowo przedstawia chorwacką poezję miłosną renesansu, choć równocześnie zastrzega, że rozdziały poświęcone renesansowym lirykom nie mają charakteru wyczerpujących monografii. Sięga po utwory piętnasto- i szesnastowiecznych autorów: oprócz Džore Držicia (1461-1501) także Šišmunda Menčeticia (1457-1527), anonimowych poetów, których kompozycje są zawarte w słynnym Kodeksie Nikšy Ranjiny (Zbornik Nikše Ranjine), Hanibala Lucicia (1485-1553), Marina Držicia (1508-1567), Nikoli Nalješkovicia (ok. 1505-1587), Dinka Ranjiny (1536-1607), Dominka Zlataricia (15581613) i Horacja Mažibradicia (1566-1641). Korpus dzieł został dobrany stosownie do faz rozwoju twórczości petrarkistycznej oraz uporządkowany według klucza diachronicznego. Ograniczenie tomu do realizacji literackich z XV i XVI wieku jest świadomym wyborem autora, co odpowiada 
temporalnym ramom renesansu, wyznaczanym przez tradycyjny schemat periodyzacyjny, a także pozostaje w zgodzie z granicami czasowymi samego nurtu petrarkistycznego.

Warto zaznaczyć, że chorwacka renesansowa poezja miłosna była rzadko badana przez historyków literatury. Refleksje na jej temat pojawiały się w publikacjach podręcznikowych i to zwykle w formie obowiązkowego komunikatu czy też syntetycznego, nader ogólnego omówienia albo jej opisowi towarzyszyły wciąż te same szablonowe, nieustannie ponawiane i dawno zużyte teorie, koncepcje, konstrukcje myślowe, które w znakomitej większości traktowały o homogeniczności chorwackiej liryki miłosnej. Istnieje niewiele opracowań, które szerzej i w oryginalny sposób podejmowałyby problematykę opisywanej twórczości poetyckiej. Te, które od lat funkcjonują w obiegu, czy to w postaci monograficznych publikacji, czy kompendiów wiedzy o historii literatury, skupiają się wyłącznie na kilku nazwiskach, z reguły są to: Džore Držić, Marin Držić czy Hanibal Lucić, prawie nie pojawiają się w nich tacy twórcy, jak Šišmundo Menčetić, Dinko Ranjina, nie wspominając już o Horaciju Mažibradiciu. Za słuszną należy uznać opinię autora, że brak zainteresowania tymi dziełami stoi w jawnej sprzeczności z ważnością i wartością literacką tej poezji. W świetle sporadycznej raczej obecności wymienionych utworów w chorwackiej refleksji, nie mówiąc już o zagranicznej (w tym także polskiej), dla której literatura chorwacka nie jest macierzystą/narodową, wskazywana tu rozprawa zasługuje na uwagę chociażby ze względu na wybór zagadnienia, twórców, szeroki wachlarz prezentowanych realizacji poetyckich; zwłaszcza że jest to wyjątkowo udana publikacja także pod względem warsztatu badawczego, rzetelności naukowej.

Książka stanowi przemyślaną, spójną prezentację piętnasto- i szesnastowiecznej miłosnej liryki chorwackiej, jej narracja jest silnie osadzona w nurcie współczesnych badań literaturoznawczych. Autor rozpoczyna swój wywód od teoretycznego wstępu, nakreśla najważniejsze problemy i ścieżki interpretacyjne, wyznacza także wyraźne granice pola badawczego, następnie szeroko odwołuje się do nowoczesnych, wypracowanych przede wszystkim w środowiskach niemieckich i anglosaskich, teorii oraz koncepcji związków liryki i podmiotu tekstualnego, renesansowej poezji i jej charakterystycznego rdzenia, jakim był w europejskiej (w tym właśnie w chorwackiej) literaturze petrarkizm. W centralnej części rozważań 
znajduje się oczywiście chorwacka liryka miłosna, która jest traktowana jako jedność w różniących się od siebie realizacjach poetyckich, a sama strategia badawcza odnosi się zarówno do teorii liryki jako rodzaju literackiego, jak i do petrarkizmu jako tradycji konstytutywnej w renesansowej literaturze.

W obu perspektywach kluczową kwestią jest związek liryki i podmiotu tekstualnego, który w książce Tomislava Bogdana ujawnia się na płaszczyźnie formalnej, komunikacyjnej i fenomenalizującej ów podmiot. Zasadniczy w opisie chorwackiej poezji XV i XVI wieku subiekt tekstualny, eksponowany $\mathrm{w}$ szerokim kontekście historycznoliterackim i kulturowym, uznawany za „konstrukcję, wytwór języka, ideologii i mechanizmów mocy [...] wytwór dyskursu i wyłącznie tekstualny element" (s. 10), wymiennie nazywany subiektem/podmiotem tekstu lub tekstualną podmiotowością, jest przez autora omawiany w kilku aspektach. Tomislav Bogdan postrzega go w kategoriach wewnętrznej pragmatyki tekstu, czyli komunikacji słownej i kontekstualizacji sensu, a także fikcjonalnej, tekstualnej świadomości czy wręcz osobowości (w tym przypadku gry różnorodnych dyskursów miłosnych) oraz w świetle powiązań wewnątrztekstowych fenomenów i ich historycznych kontekstów.

Jednym z głównych problemów podjętych w pracy jest pojęcie petrarkizmu i nieustannie towarzyszący mu w przestrzeni literaturoznawczej, a szerzej kulturowej, uniform definicyjny, sprowadzający tradycję ukształtowaną na gruncie petrarkizmu do jednolitej, spójnej postaci i homogenicznej projekcji. Dodatkowo podniesiony zostaje fakt nadmiernej pojemności terminu, bo nie bez racji autor zwraca uwagę na nieuprawnione i nazbyt częste, szczególnie w starszej refleksji literaturoznawczej, utożsamienie petrarkizmu z renesansową liryką miłosną. Tego rodzaju postrzeganie wyklucza obecność w tej poezji innych (różnych) tradycji czy dyskursów miłosnych, nie odzwierciedlając tym samym faktycznego stanu rzeczy, co zostaje również w rozprawie wykazane na konkretnych przykładach, uwypuklone na podstawie zróżnicowania poetyk poszczególnych twórców. Co więcej, w całym wywodzie w rozprawie została podkreślona heterogeniczność, wielowymiarowość znaczeniowa i pluralistyczny charakter samej tradycji petrarkistycznej w dziełach poetów reprezentatywnych dla renesansowej literatury chorwackiej. Można więc ten wysiłek ocenić jako nowe podejście badawcze w obrębie chorwackiej nauki, 
znakomicie wpisujące się w nowoczesny, europejski nurt badań historycznoliterackich, zapoczątkowany między innymi przez teorie Gerharda Regna, Klausa Hempfera, Rainera Warninga; kierunek obowiązujący w myśli intelektualnej końca XX stulecia, który jest nadal aktualny i rozwijany.

Znaczącym osiągnięciem rozprawy Tomislava Bogdana jest ujawnienie wielopostaciowości renesansowych lirycznych dyskursów miłosnych oraz sporządzenie swoistej typologii podmiotu tekstualnego. Zależność między subiektem i dyskursem - mająca istotny wpływ czy też odzwierciedlająca się w organizacji tekstu, strategii narracyjnej, stylistyce wypowiedzi, wewnątrztekstowej komunikacji oraz statusie nadawcy, aktora lirycznego, odbiorcy - została także czytelnie i wieloaspektowo zaprezentowana.

Autor zwraca uwagę nie tylko na zróżnicowanie renesansowej poezji chorwackiej jako całości, ale też na niejednorodność dyskursów miłosnych w twórczości poszczególnych poetów. Uwydatnia przy tym funkcjonalność wielkiego wzorca, a właściwie stosunek rodzimych twórców do petrarkistycznego schematu, zakres jego adaptacji, zastosowania lub też odstępstwa od wyznaczanej przezeń normy.

Omawiana publikacja stanowi nieklasyczną prezentację klasyki, udaną próbę przełamania tradycyjnych i dawno zużytych szablonów opisywania literatury. Autor wpisuje swój wywód w nurt nowoczesnych badań literaturoznawczych, stawiając wiele oryginalnych tez i budując własne koncepcje, nade wszystko zaś ożywiając refleksję na temat renesansowej poezji chorwackiej. 